2008

\title{
Cartel Overcharges and Optimal Cartel Fines
}

John M. Connor

Purdue University

Robert H. Lande

University of Baltimore School of Law, rlande@ubalt.edu

Follow this and additional works at: http://scholarworks.law.ubalt.edu/all_fac

Part of the Antitrust and Trade Regulation Commons, and the Consumer Protection Law Commons

\section{Recommended Citation}

Cartel Overcharges and Optimal Cartel Fines, in 3 Issues in Competition Law and Policy 2203 (ABA Section of Antitrust Law 2008)

This Book Chapter is brought to you for free and open access by the Faculty Scholarship at ScholarWorks@University of Baltimore School of Law. It has been accepted for inclusion in All Faculty Scholarship by an authorized administrator of ScholarWorks@University of Baltimore School of Law. For more information, please contact snolan@ubalt.edu. 


\title{
CARTEL OVERCHARGES AND OPTIMAL CARTEL FINES
}

\author{
John M. Connor \& Robert H. Lande *
}

This Chapter examines how high cartels raise prices on average and what this should mean for the current criminal fine levels in the United States Sentencing Guidelines. We utilize two distinct data sets (economic and other studies, and verdicts in final cartel cases) and find that cartels have caused average overcharges in the range of $31 \%$ to $49 \%$ and median overcharges in the range of $22 \%$ to $25 \%$ of affected commerce. The authors conclude that the current Sentencing Commission presumption that cartels overcharge on average by $10 \%$ is much too low, and the current levels of cartel penalties should be increased significantly.

\section{Introduction}

The standard optimal deterrence model shows how to structure penalties to deter antitrust violations so society is, overall, better off. In light of the problems of overdeterrence and underdeterrence that can arise, this means that a violator's fine should be equal to the violation's net harm to others divided by the probability of detection, enforcement, and proof of the violation. ${ }^{2}$ Applied to antitrust violations, it will be shown that this can be expressed in the following simple rule:

monopoly overcharge < (net harm to others) $\div$ (probability of conviction) = optimal fine

In most cartel cases the bulk of the social costs - the "net harm to others" - resides in the aggregate monopoly overcharge, so the size of the overcharge should be a critical factor in determining the optimal antitrust fine. It is important to note, however, that in addition to these overcharges, a cartel's social harm includes other, less obvious factors that typically are not taken into account in the fashioning of criminal fines. First, market power can produce allocative inefficiency, represented by the deadweight loss welfare triangle in the standard diagram of

\footnotetext{
* Purdue University and the University of Baltimore School of Law, respectively. The authors also are, respectively, members of the Advisory Board and the Board of Directors of the American Antitrust Institute. This chapter is a condensed and updated revision of John M. Connor \& Robert H. Lande, How High Do Cartels Raise Prices: Implications for Optimal Cartel Fines, 80 TULANE L. REv. 513 (2005). Some of the updates are found in John M. Connor and Robert H. Lande, The Size of Cartel Overcharges: Implications for U.S. and EU Fining Policies 51 ANTITRUST BULL. 983 (2006).

${ }^{2}$ See, e.g., William M. Landes, Optimal Sanctions For Antitrust Violations, 50 U. CHI. L. REV. 652, 656 (1983). Landes built upon and applied to antitrust a framework developed in Gary S. Becker, Crime and Punishment: An Economic Approach 76 J. POL. ECON. 169 (1968), and George J. Stigler, The Optimum Enforcement of Laws, . 78 J. Pol. Econ. 526 (1970). Professor Landes' analysis gave no weight to the compensation of victims. For an analysis that takes compensation into account see Robert H. Lande, Are Antitrust "Treble" Damages Really Single Damages, 54 OHIO ST. L.J. 115, 161-68 (1993).
} 
monopoly pricing. The deadweight loss, which often can be significant, ${ }^{6}$ apparently has never been awarded in an antitrust case. ${ }^{7}$ Second, market power can produce umbrella effects, which occur when a cartel permits or causes non-conspiring firms to charge higher prices under the "umbrella" of its supracompetitive price. ${ }^{9}$ Third, cartel members may have less incentive to innovate or to optimize variety or quality, which results in harm to society. ${ }^{10}$ Finally, when monetized, monopoly overcharges have a time-value, yet antitrust fines do not include a prejudgment interest adjustment. ${ }^{11}$ Given the failure of courts to take these factors into account when calculating fines, ${ }^{12}$ it is likely that even if an accurate accounting of the monopoly overcharge could be determined, the resulting fines are likely to be significantly less than the optimal fines.

Moreover, since not every cartel is detected or successfully proven, the optimal fine should be larger than a cartel's net harm to others. ${ }^{14}$ Indeed, under the simple version of the theory, captured in the equation above, this multiplier should be the inverse of the probability of detection, enforcement, and proof. Of course, no one knows the percentage of cartels that are detected and proven. In 1986, the Assistant Attorney General for Antitrust, Douglas H. Ginsburg

\footnotetext{
6 Frank H. Easterbrook, Detrebling Antitrust Damages, 28 J.L. \& ECON. 445, 455 (1985). Judge Easterbrook made a number of simplifying assumptions and then concluded that the allocative inefficiency was likely to be half as large as the overcharge on average. From this he calculated that, if we believe antitrust damages should be three times their harms, due to the omission from damage awards of allocative inefficiency alone, “'[t]reble damages' are really [only] double the starting point of overcharge plus allocative loss. . . " Id.

7 See David C. Hjelmfelt \& Channing D. Strother, Jr., Antitrust Damages For Consumer Welfare Loss, 39 CLEV. ST. L. REV. 505 (1991). See also William B. Page (Genl. Ed.), PROOVING ANTITRUST DAMAGES: LEGAL AND ECONOMIC DAMAGES (1996) at 17-18 ("Despite the obvious problems of proof,... [this] harm appears to be antitrust injury"). We recently performed our own search and also did not find such a case.
}

9 Phillip E. Areeda \& Herbert Hovenkamp, Antitrust Law 384-85 (Supp. 1992). To illustrate, OPEC never produced even $70 \%$ of the free world's supply of oil. See Mohammed E. Ahrari, OPEC: ThE FaILING GiAnt 203 (1986). Yet, when OPEC raised prices, noncartel members also increased oil prices. See OPEC, ANNUAL STATISTICAL BULLETIN 20 (2004), available at http://www.opec.org/library/Annual\%20Statistical\% Bulletin/pdf/ASB2004.pdf (last visited Jan. 18, 2005). Moreover, the price of fuels that were partial substitutes for oil, such as natural gas, also rose. See, e.g., Stephen P.A. Brown, Natural Gas Pricing: Do Oil Prices Still Matter?, Southwest Econ. 4 (Fed. Res. Bank of Dallas July/Aug. 2005), available at http://www.dallasfed.org/research/swe/2005/swe0504c.html; Mine K. Yucel \& Shengyi Guo, Fuel Taxes and Cointegration of Energy Prices, CONTEMP. ECON. POLICY 12, 33-41 (1994). Relationships between oil prices and other fuels (e.g., coal and uranium) are more difficult to establish. [WDC WILL CROSS-REFERENCE TO BLAIR AND PIETTE CHAPTER] Courts rarely include umbrella effects as part of a damages award.

10 See generally Neil W. Averitt \& Robert H. Lande, Using the “Consumer Choice” Approach To Antitrust Law, 74 ANTITRUST L. J. 175 (2007).

11 Studies suggest that the average cartel probably lasts 7-8 years, with an additional 4 or more years lag before judgment. This can cause significant distortions unless fines reflect this time lag. See Robert H. Lande, Are Antitrust “Treble” Damages Really Single Damages, 54 OHIO ST. L. J. 130-34 (1993).

12 In light of the omissions of these factors, antitrust's private "treble damages" remedy probably is really only .48 to 1.09 - roughly one time as large - as the violations' net harm to others. Id. at 158-61. This study did not, however, consider the effects of criminal fines or prison terms on optimal deterrence.

${ }^{14}$ See Frank H. Easterbrook, Detrebling Antitrust Damages, 28 J.L. \& ECON. 445, 455 (1985) ("Multiplication is essential to create optimal incentives for would-be violators when unlawful acts are not certain to be prosecuted successfully. Indeed, some multiplication is necessary even when most of the liability-creating acts are open and notorious. The defendants may be able to conceal facts that are essential to liability."). 
opined that the enforcers detected no more than $10 \%$ of all cartels. ${ }^{16}$ There certainly are reasons to believe that the Antitrust Division's amnesty program has resulted in a much larger percentage of cartels detected and proven today, ${ }^{17}$ but there is anecdotal evidence that, despite the enforcers' superb efforts, many cartels still operate. ${ }^{18}$ Although we do not know the percentage of cartels that are detected and convicted, since some go unpunished we safely can conclude that if the combined antitrust sanctions only total one times the net damages caused by the violation, firms are underdeterred from committing cartel violations. ${ }^{19}$

Adherents of both the Chicago and post-Chicago schools of antitrust have almost universally accepted these principles. ${ }^{21}$ The analytics can become much more complicated when potential violators are not risk neutral, where potential violators have uncertainty or imperfect information concerning the relevant parameters, ${ }^{22}$ and when there are adverse consequences to a violator other than fines (such as imprisonment or private treble damages), but the basic insight of the theory remains intact. ${ }^{23}$

Surprisingly, there has been relatively little systematic exploration of a key factor involved in determining optimal deterrence: the overcharges from cartel activity. This chapter's

\footnotetext{
${ }^{16}$ Douglas H. Ginsburg, Statement to the United States Sentencing Commission 15 (July 15, 1986). See United States Sentencing Commission: UnPUBLISHED PUBLIC HEARINGS, 1986 volume, July 15, 1986 Hearing, at 15.

${ }^{17}$ See generally Gary R. Spratling, Detection and Deterrence: Rewarding Informants for Reporting Violations, 69 GEO. WASH. L. REV. 798, 817-23 (2001).

${ }^{18}$ The continued high number of Department of Justice (DOJ) grand juries, and the recent DOJ success rate in these cases, is evidence that many cartels still exist. Between 1996 and 2005, the DOJ opened from 19 to 48 grand jury investigations per year, most of which resulted in convictions. Antitrust Div., U.S. Dep't of Justice, Workload Statistics: FY 1996-2005, at http://www.usdoj.gov/atr/public/workstats.htm (last visited Feb. 19, 2007). Since 1996 the government has won more than $90 \%$ of these cases each year. Id. "[I]n fiscal years 2004 and 2005, and so far in 2006, the Antitrust Division of the Department of Justice has obtained fines of \$360 million, \$338 million, and \$473 million, respectively, and has brought criminal cases against 69 firms.” Thomas O. Barnett, Assistant Attorney General, U.S. Dep't of Justice, Speech at the Fordham Competition Law Institute's Annual Conference on International Antitrust Law and Policy: Criminal Enforcement Of Antitrust Laws: The U.S. Model. (Sept. 14, 2006) available at http://www.usdoj.gov/atr/public/speeches/218336.htm. See John M. Connor and C. Gustav Helmers, STATISTICS ON MODERN PRIVATE INTERNATIONAL CARTELS, 1990-2005: The American Antitrust Institute Working Paper No. 07-01 (2007) (a comprehensive study that finds a total of 283 international cartels convicted or under investigation from 1990 to 2005 and finds more than 170 cartel recidivists).
}

${ }^{19}$ The combined antitrust sanctions should also include the effects of prison time and private treble damages actions. We make no attempt, however, to account for these factors in this chapter. We are only focusing upon criminal fines.

${ }^{21} I d$. at $161-68$.

${ }^{22}$ For example, instead of attempting to ascertain the actual probability of detection and conviction, one could focus upon the perceptions of probable defendants. It would be extremely useful to know potential price fixers' perceptions of the probability that they will be caught and convicted and their belief as to how much they will be forced to pay. We know of no reliable information on this issue, however.

${ }^{23}$ See A. Mitchell Polinsky \& Steven Shavell, the The Economic Theory of Public Enforcement of the Law, 38 J. ECON. LITERATURE 45 (2000): Nuna Garoupa, Theory of Optimal Law Enforcement, 11 J. ECON. SURVEYS 267 (1997); Jonathan B. Baker, Private Information and the Deterrent Effect of Antitrust Damages Remedies, 4 J. L. ECON., AND ORGANIZATION 385 (1988); Mitchell Polinsky \& Steven Shavell, The Optimal Tradeoff Between the Probability and Magnitude of Fines, 69 AMERICAN ECON.REV. 880 (1979). 
goal is to increase our knowledge in the area by surveying the available studies and presenting new data on cartel overcharges. To do this, first Section 2 briefly examines the Sentencing Guidelines used in the United States and the evidence before the Sentencing Commission on the magnitude of cartel overcharges when it issued the current fining Guidelines. Section 3 surveys others' studies of cartel price effects, and Section 4 presents our own, comprehensive, survey of these effects. Section 5 provides our survey of price effect data from the final verdicts in cartel cases. Finally, Section 6 offers some conclusions and implications.

\section{Estimates of overcharges in the U.S. Sentencing Guidelines}

The U.S. Sentencing Guidelines, ${ }^{24}$ which are not mandatory ${ }^{25}$ and are not the only set of provisions used to calculate criminal fines for cartels, ${ }^{26}$ provide that the base fine level generally will be $20 \%$ of the volume of affected commerce. ${ }^{27}$ This flows from the "estimate" that "the average gain from price-fixing is $10 \%$ of the selling price." 28 The U.S. Sentencing Commission doubled this $10 \%$ estimate to $20 \%$ to account for harms "inflicted upon consumers who are unable or for other reasons do not buy the product at the higher price." 29 The Commission noted that " $[\mathrm{t}]$ he purpose for specifying a percent of the volume of commerce is to avoid the time and expense that would be required for the court to determine actual gain or loss." 30

The Sentencing Guidelines start with this base fine of double the $10 \%$ "estimated" overcharge and adjust it by a number of factors, such as whether bid-rigging ${ }^{31}$ and other aggravating factors are involved, and by mitigating factors as well. ${ }^{32}$ A series of adjustments related to the degree of culpability result in the actual fine that is to be imposed on a cartel member. For example, the fines usually are adjusted downwards for cooperation. ${ }^{33}$ As the Sixth

\footnotetext{
24 U.S. SENTENCING GUIDELINES MANUAL $§ 2 R 1.1$ (2006).

25 See United States v. Booker, 543 U.S. 220 (2005). (hereafter “Booker") In addition, Rita v United States, 2007 WL 1772146 (U.S.S.C. June 21, 2007) recently held that judges who follow the U.S. Sentencing Guidelines are presumed to have acted reasonably.

${ }^{26}$ For a brief discussion of the amnesty program and of other relevant factors used to determine criminal fines see John M. Connor \& Robert H. Lande, How High Do Cartels Raise Prices: Implications for Optimal Cartel Fines, 80 TULANE L. REV. 513, 522-23 and the sources cited therein (2005).

27 U.S. Sentencing Guidelines Manual § 2R1.1(d)(1) (2006).

${ }^{28} I d$. at $\S 2 \mathrm{R} 1.1$ application note 3 .

$29 I d$. (this appears to be a reference to the deadweight loss).

${ }^{30} I d$. (as an alternative to the U.S. Sentencing Guidelines, the courts may apply 18 U.S.C. $\$ 3571$ to calculate a fine based on the larger of double the gain or double the loss due to cartelization of a market; computation of the gain or loss is conventionally regarded as more difficult than formulas based on affected commerce).

31 If bid-rigging is involved the Base Offense Level is increased by 1. See id. at $\S 2 \mathrm{R} 1.1$ (b).

32 See id. at $\S 2 \mathrm{R} 1.1 \&$ application note 1.

${ }^{33}$ For a discussion and citations see Gary R. Spratling, : Detection and Deterrence: Rewarding Informants for Reporting Violations, 69 GEO. WASH L. R.. 798, 817-23 (2001).
} 
Circuit noted, the Sentencing Commission "opted for greater administrative convenience instead of undertaking a specific inquiry into the actual loss in each case.",34

The crucial $10 \%$ estimate was first advanced by the then-head of the Antitrust Division, Douglas H. Ginsburg, who testified before the Commission that "price fixing typically results in price increases that [harm] the consumers in a range of $10 \%$ of the price"35 While the record does not disclose how Ginsburg arrived at his $10 \%$ overcharge estimate, a prominent analysis published shortly thereafter states that the economic evaluation of a very small number of pricefixing conspiracies was particularly important in shaping the conclusions of Ginsburg and the U.S. Sentencing Commission that the overcharges from price-fixing conspiracies were approximately $10 \% .^{38}$

\section{Prior Surveys of Cartel Price Effects Studies}

There have been several surveys of studies on the price effects of individual cartels. Several authors have even undertaken limited surveys of this literature, the best known of which was performed by Judge Posner. Posner analyzed overcharges from cartelization by assembling data on twelve "well-organized (mainly international) private cartels." 42 He noted that "[s]uch estimates enable us to derive a crude and probably exaggerated, but nonetheless suggestive idea of the potential benefits of antitrust policy." 43 The various studies yield a median cartel overcharge of $38 \%$ and an average cartel overcharge of $49.1 \%$. See Table 1 . The low overcharge was $7 \%$ and the high was $100 \%{ }^{44}$

Table 1. Summary of Seven Economic Surveys of Cartel Overcharges

\begin{tabular}{|c|c|c|}
\hline \multirow{2}{*}{ Reference } & Number of & Average Overcharge \\
\hline & Cartels & Median \\
\hline
\end{tabular}

34 See United States v. Hayter Oil Co., 51 F.3d 1265, 1277 (1995) ("The offense levels are not based directly on the damage caused or profit made by the defendant because damages are difficult and time consuming to establish. The volume of commerce is an acceptable and more readily measurable substitute....").

35 Douglas H. Ginsburg, Statement to the United States Sentencing Commission 13-14 (July 15, 1986). See United States Sentencing Commission: UNPUBLISHED PuBliC HeARINGS, 1986 VOLUME, July 15, 1986 Hearing, at 14. It is perhaps no coincidence that two economists at the Antitrust Division published a thoughtful analysis of many of these issues at roughly the same time. See Gregory J. Werden \& Marilyn J. Simon, Why Price Fixers Should Go To Prison, 32 ANTITRUST Bull. 917 (1987). This article briefly surveyed a few cases, and on this basis concluded that a "[c]onservative estimate of the average price increase from price fixing is $10 \%$." Id. at 924-25.

38 See Mark A. Cohen \& David T. Scheffman, The Antitrust Sentencing Guideline: Is the Punishment Worth the Cost?, 27 AM. CRIM. L. REV. 331, 342-45 (1989).

42 Richard A. Posner, ANTITRUST LAW (2d ed. 2001) at 303-04.

43 Id. at 304.

44 Id. Interestingly, Judge Ponser recently cited, with apparent approval, the conclusion of Connor \& Lande that "[t]he median cartel overcharge has been estimated at 25 percent." See Richard A. Posner, ECONOMIC ANALYSIS OF LAW (7th ed. 2007) at 312 n. 3. Judge Posner did not, however, cite his earlier survey. 


\begin{tabular}{lccc}
\hline 1. Cohen and Scheffman (1989) & $5-7$ & $7.7-10.8$ & $7.8-14.0$ \\
2. Werden (2003) & 13 & 21 & 18 \\
3. Posner (2001) & 12 & 49 & 38 \\
4. Levenstein and Suslow (2002) & 22 & 43 & 44.5 \\
5. Griffin (1989), private cartels & & & 44 \\
6. OECD (2003), excluding peaks & 38 & 46 & 12.75 \\
& 12 & 15.75 & 28.1 \\
$\begin{array}{l}\text { Total, simple average } \\
\text { Total, weighted average }\end{array}$ & $102-104$ & 30.7 & 34.6 \\
\hline
\end{tabular}

Several other surveys have been done, including a recent survey of collusion cases by Gregory J. Werden, ${ }^{46}$ a survey by Margaret C. Levenstein and Valerie Y. Suslow, ${ }^{47}$ and a larger survey by James M. Griffin. ${ }^{48}$ The most authoritative survey was in 2003 by the Organization for Economic Cooperation and Development (OECD). ${ }^{49}$ Its report on hard core cartels contains responses from its government members regarding the economic harm caused by cartels recently prosecuted by the European Commission or by OECD members' national antitrust authorities.

\footnotetext{
${ }^{46}$ Gregory J. Werden, The EFFeCt OF ANTITRUSt Policy ON CONSUMER Welfare: What CRANDALL AND Winston OVERLOoK (U.S. Dep't of Justice Antitrust Division Discussion Paper No. EAG 03-2, January 2003). His sample selection criterion suggest why his results are lower than those obtained by Posner: Werden reviews only criminally prosecuted cartels in existence after enactment of the felony provisions of the Sherman Act in late 1974, whereas Posner's sample is chosen from cartels that mainly operated between 1920 and 1939 and were particularly "well organized". As Werden notes, the price effects of cartels at earlier times may have been substantially different than those in effect after 1974 because sanctions were less severe.

${ }^{47}$ Margaret C. Levenstein and Valerie Y. Suslow, What DETERMINES CARTEL SUCCESS? (University of Michigan Business School Working Paper No. 02-001, revised January 31, 2002). However, the article's estimates appear to include some peak, rather than average figures, so the median and mean figures may be somewhat high.

48 James M. Griffin, Previous Cartel Experience: Any Lessons for OPEC?, in ECONOMICS IN THEORY AND PRACTICE: AN ECLECTIC APPROACH 179 (L.R. Klein \& J. Marquez eds., 1989). We eliminated from his survey the episodes that were government sponsored and therefore not the subject of this article.

49 OECD, REPORT ON THE NATURE AN IMPACT OF HARD-CORE CARTELS AND SANCTIONS AGAINST CARTELS UNDER NATIONAL COMPETITION LAWS, Annex A (2003).
} 


\section{Our Survey of Cartel Price Effects Studies}

To developed a more comprehensive survey, we examined cartel studies in more than 500 refereed journal articles, working papers, monographs, and books, but fewer than half contained usable quantitative overcharges. ${ }^{53}$ These studies vary substantially in terms of depth, professional orientation, and date of publication. We utilized 82 peer reviewed journal articles, many of which contained multiple estimates. The second most frequent source of estimates was 55 books or chapters in books. ${ }^{55}$ Other sources include reports issued by antitrust agencies, parliamentary inquiries, and multilateral organizations. Our aim was to collect the largest possible body of information on the subject, eschewing some sort of subjective quality screening. We excluded from our survey cartels that were established or actively supported by governmental action. Because of this study's antitrust orientation, commodity agreements sponsored or protected by national sovereignty are not included because they would tend to bias upward the overcharges in our sample. In general we aimed to follow procedures that yield conservative results. ${ }^{58}$

Consistent with most previous studies of cartel effectiveness, we treated each cartel episode as a unique observation. Most cartels are organized and fall apart only once, not counting brief disciplinary price wars. This describes one episode. However, many cartels are formed, disband, reform, and disband several times; each distinct cycle is an episode. We found 674 useful average estimates of cartel overcharges or undercharges in about 200 publications that analyzed cartels in 234 markets. ${ }^{59}$ Of these markets, $36 \%$ were cartelized by international agreements ${ }^{60}$ almost one third were bid-rigging schemes, and about $60 \%$ were found guilty by an antitrust authority. Researchers usually report the average price increases over the whole episode $^{61}$

\subsection{Results of the survey}

The overcharge estimates are presented in Table 2, divided into periods that represent different antitrust regimes in the United States and abroad. ${ }^{62}$ The median cartel overcharge for all types and time periods (a median that includes a significant number of zeros) is $25 \% .^{63}$ There is a

\footnotetext{
${ }^{53}$ For more information about these sources see John M. Connor \& Robert H. Lande, How High Do Cartels Raise Prices: Implications for Optimal Cartel Fines, 80 Tulane L. ReV. 513, 533-37 (2005).

${ }^{55} \mathrm{Id}$.

${ }^{58}$ For the methodology involved see $i d$.

${ }^{59} I d$. at 535-36.

${ }^{60}$ International describes the membership composition of the cartel, not necessarily the geographic spread of the cartel's effects. Some international cartels affected directly the commerce of only one nation, though the vast majority was international in both senses.

${ }^{61} \mathrm{We}$ also found many studies that only reported peak price effects. Generally speaking, the peaks were at least $50 \%$ higher and typically were more than double the average price enhancement achieved.

${ }^{62}$ The authors choose to show the median overcharge percentages because the data are positively skewed. In such situations the means are larger than the medians, and the median is a better representation of central tendency.

${ }^{63}$ The successful cartels (those with positive overcharges) had median average 28\%-29\% overcharges.
} 
downward trend over time in cartel mark ups for most cartel types. ${ }^{64}$ However, for two of the six types of cartels, bid rigging and "legal" (i.e., unpenalized), there is no significant decline in average overcharges. While the causes of the downtrends in profitability for most types of cartels are uncertain, the influence of the spread of effective anticartel enforcement is perhaps the most obvious explanation. Alternatively, the greater antitrust scrutiny in the United States from the 1940s and from Europe since the 1960s could have prompted cartelists to refrain from full monopoly pricing increases so as to reduce the chances of detection. ${ }^{65}$

A second pattern that emerges in Table 2 is that in every period international cartels have been more injurious than (mostly U.S.) national cartels. In general, international cartels are about $75 \%$ more effective in raising prices than domestic or national cartels. ${ }^{66}$ The clearly greater price effectiveness demonstrated by international agreements may reflect a greater degree of freedom from threat of entry by competitors than would be true for the geographically more localized cartels.

The cartels from which we collected the data functioned over various geographic areas. ${ }^{67}$ Some confined their operations to one nation, some to several countries in one continent, and some straddled continents (the last we refer to as global). The results show that those in single European countries have the lowest median overcharges (17\%) but, international cartels organized across national boundaries in Western Europe were as a group the most successful (43\% median overcharge). North American conspiracies also had quite low average overcharges (21\%). Median overcharges for Asian-based and global conspiracies were high (29\%). ${ }^{68}$

\footnotetext{
${ }^{64}$ We tested this proposition by applying simple correlation analysis. We correlated the year at the midpoint of the affected period of a cartel with the percentage cartel overcharge. The sample is derived from a study of several hundred observations, and is explained in John M. Connor, Price-Fixing Overcharges: Legal and Economic Evidence, 22 RESEARCH L. ECON. 59 (2007). The sample was divided into two sub samples: international cartels and cartels that functioned within a single nation. The correlation coefficients for the national and international cartels are - 0.61 and -0.64 , respectively. Because the correlation coefficients are significantly less than zero, there is a strong inverse relationship between the years in which a cartel existed and the size of the cartel's price effects. See also John M. Connor \& Yuliya Bolotova, A Meta-Analysis of Cartel Overcharges, 24 INT'L J. INDUSTRIAL ORG. 1109 (2006) (applies a multiple regression model to the same data and obtains the same negative relationship).

65 There is an overall upward trend in number of observations per year. The primary factor that explains the trend is the growth in the number international cartels with usable data. The proportion of international schemes is especially high during the interwar period and after 1990. A second important trend is that the most recent cartel data arise from prosecuted cartels. Prior to 1946 less than $30 \%$ of our observations refer to cartels known to have been prosecuted. After 1990, 90\% of the cartels in our sample were prosecuted or fined by one or more antitrust authority. This pattern does not necessarily mean that the probability of discovery by prosecuting bodies has gone up significantly, but it probably does represent a heightened aggressiveness in anticartel enforcement as well as a shift in research methods by social scientists. A third trend is the increasing prominence of estimates derived from bidrigging conspiracies; after 1973, half of the episodes involved rigged bids. Relatively few international cartels rely primarily of rigging auctions or tenders for public projects.

66 This is not so surprising in the pre-World War II era because international cartels were formed without concern about prosecution, and even in the interwar period U.S. companies may have believed that they had structured their participation in ways that would not run afoul the Sherman Act. But the fact that the differences persisted in the postwar period is somewhat unexpected.

${ }^{67}$ See John M. Connor and Robert H. Lande, The Size of Cartel Overcharges: Implications for U.S. and EU Fining Policies 51_ANTITRUST BulL. 983, 1012 (2006).

${ }^{68}$ Id. at 1008
} 
Table 2. Median of Average Cartel Overcharges by Year and Type

\begin{tabular}{|c|c|c|c|c|c|c|c|}
\hline \multirow{2}{*}{$\begin{array}{l}\text { Cartel Episode } \\
\text { End Date }\end{array}$} & \multicolumn{2}{|c|}{ Membership } & \multicolumn{2}{|c|}{ Legal Status } & \multicolumn{2}{|c|}{ Conduct } & \multirow{2}{*}{$\begin{array}{l}\text { All } \\
\text { Types }\end{array}$} \\
\hline & National & $\begin{array}{l}\text { Inter- } \\
\text { national }\end{array}$ & $\begin{array}{l}\text { Found } \\
\text { Guilty }\end{array}$ & Legal & $\begin{array}{l}\text { Bid } \\
\text { Rigging }\end{array}$ & Other & \\
\hline & \multicolumn{7}{|c|}{ Median Percent $^{a}$} \\
\hline $1780-1890$ & 22 & 41 & 32 & 22 & 16 & 24 & 23.5 \\
\hline 1891-1919 & 21 & 48 & 25 & 35 & 28 & 37 & 30.4 \\
\hline $1920-1945$ & 18 & $36-37$ & 45 & 32 & 34 & 34 & 34.0 \\
\hline 1946-1973 & 14 & 26 & 13 & 23 & 13 & 15 & 15.0 \\
\hline 1974-1990 & $18-20$ & $40-43$ & 22 & 37 & 21 & $25-26$ & 24.0 \\
\hline 1991-2004 & $17-18$ & 25 & $24-25$ & 20 & 22 & 25 & 24.0 \\
\hline ALL YEARS & $17-19$ & $30-33$ & $23-25$ & 28 & 21 & $25-29$ & 25.0 \\
\hline
\end{tabular}

Source: John M. Connor \& Robert H. Lande, How High Do Cartels Raise Prices: Implications for Optimal Cartel Fines, 80 TULANE L. REV. 513, 539 (2005).

${ }^{a}$ Medians of the lower bounds or the upper bounds of ranges, where appropriate. Includes many zero estimates.

A third finding is the lower price effects of bid-rigging cartels (median 21\%) compared to conventional conspiracies that set selling prices or allocate market shares (25-29\%). ${ }^{69}$ Bid rigging occurs mostly in national or local conspiracies, so this finding may be confounded with the geographic types just discussed above. Nevertheless, this finding directly contradicts the U.S. Sentencing Guidelines that impose higher penalties for bid rigging. It also challenges a rationale of the U.S. Government's overt policy shift in the 1980s that made bid rigging a higher priority.

Moreover, it is striking that $79 \%$ of the overcharges are above the $10 \%$ presumption that is the cornerstone of the Sentencing Guidelines.$^{70}$ Indeed, $60 \%$ of the cartel episodes have overcharges above $20 \%{ }^{71}$ If the Guidelines' fines are supposed to be large enough to deter future antitrust violations, they clearly appear far too low for the task.

\subsection{Reliability of Studies}

Three approaches were taken to assess the reliability of the various overcharge estimates reported in the previous section. First, confidence in the estimates may be judged in part by the sources from which the overcharge estimates were derived. Many of the estimates are drawn from academic books and book chapters. Peer-reviewed journals account for $65 \%$ of the total and appear to report slightly lower overcharges. ${ }^{72}$ The majority of the government reports ( $4 \%$ of the estimates) were authored by civil servants with specialized training in economics and typically these reports were vetted by a panel of experts. In total, four-fifths of the estimates

\footnotetext{
${ }^{69} \mathrm{Id}$. at $1008 .$.

${ }^{70}$ John M. Connor \& Robert H. Lande, How High Do Cartels Raise Prices: Implications for Optimal Cartel Fines, 80 Tulane L. REV. 513 (2005) at 545.

${ }^{71}$ Id

${ }^{72} I d$. at 547-48 (2005).
} 
were drawn from the formal or informal writings of academic social scientists, and most of the remainder were the product of professionally trained individuals subject to the checks and balances of internal reviews. Courts and competition agencies accounted for $12 \%$ of the estimates.

Second, we examined whether there were systematic differences between the average overcharges across time, using the date of publication of the study as a proxy for analytical advances. The intuition here is that the authors of more recent empirical studies of cartels have learned to avoid the methodological pitfalls of their predecessors. ${ }^{73}$ It is not clear that the level of overcharges varies systematically over time. ${ }^{74}$

The third check on reliability of estimates across various analytical methods controls for changes in the composition of the sample by focusing on pairs of estimates applied to identical cartel episodes. There are 291 pairs of observations available for this analysis of reliability, which examines six general methods of estimation. ${ }^{75}$ By and large, different authors and different methods applied to identical cartel episodes do not result in markedly different estimates. ${ }^{76}$

\section{Survey of Final Verdicts in Cartel Cases}

The amount that prices changed is not relevant to the issue of whether a cartel violated the antitrust laws. ${ }^{77}$ It therefore is unnecessary for the court in criminal antitrust cases to calculate the extent of any overcharges or undercharges. ${ }^{78}$ In civil cases, however, the damages awarded to

\footnotetext{
${ }^{73}$ Among the economic studies that dominate the sample, there is an undeniable trend away from mere narrative historical case studies sometimes embellished with simple graphical illustrations towards more formal statistical modeling. In industrial economics there is a trend away from evaluating cartels from the point of view of the theory of pure monopoly toward a more sophisticated and nuanced view informed by game theory and other conceptual advances. The results of a temporal analysis are displayed $I d$. at 548-49.

${ }^{74}$ Correlations of overcharges over time do show downtrends for some types of cartels, but this trend could be confounded with a greater proportion of peer-reviewed publications in current research.

75 The most widely used is the before-and-after method in which the price during the episode is compared to one of three but for or base prices. The second most popular method is statistical modeling, which accounts for $20 \%$ of the estimates. The yardstick methods accounts for about $10 \%$ of the sample. Overcharges derived from costs of production or profits are the least frequently employed method (about 3\%). Approximately 10\% of this study's estimates are quotes from or interpretations of decisions made by antitrust authorities. Id.

${ }^{76}$ Nevertheless, there are some differences. The before-and-after method produces overcharge estimates that are quite a bit higher than econometric models applied to the same data. What this result seems to suggest is that authors of traditional before and after analyses are failing to adjust for all the competitive factors that might drive up the competitive benchmark price. Second, compared with the before and after, the cost-based and yardstick techniques yield relatively high overcharge estimates. This suggests that the methods that use costs or profits fail to fully account for all competitive industry costs, perhaps those related to product marketing or overhead, or that indirect geographic spillovers from cartel activity may be more common than most analysts anticipate. If the yardsticks are product substitutes, analysts may have underestimated quality differences.

${ }^{77}$ See the discussion in Lawrence A. Sullivan \& Warren S. Grimes, THE LAW OF ANTITRUST: AN INTEGRATED HANDBOOK 165-233 (2000).

${ }^{78}$ Normally the government simply relies upon the $10 \%$ overcharge presumption. On this basis the prosecutors and the defendants typically settle upon a criminal fine without calculating the actual overcharges involved. A rare exception is United States $v$. Andreas, in which defendants were convicted of conspiring to fix the price and allocate the sales of lysine. No. 96 CR 762, 1999 WL 515484, at *2 (N.D. Ill. July 15, 1999).
} 
a successful plaintiff are equal to three times the overcharges (or, in rare cases, the undercharges) ${ }^{79}$ so a plaintiff must demonstrate how much prices increased or decreased due to the violation.

It has been extremely difficult to locate final verdicts, because almost every private antitrust suit settles or is dismissed before an overcharge can be calculated by a neutral observer and made part of the public record of the case. As a consequence, final verdicts involving cartels where a judge, jury, or commission calculated an overcharge are surprisingly rare.

Settlements, moreover, are an extremely unreliable guide as to the size of the underlying cases' overcharges. ${ }^{80}$ Settlements are by no means likely to be compromises for half of the overcharges. $^{81}$ For example, a risk-averse plaintiff with a strong case might settle for very little if it needs the money quickly. ${ }^{82}$ Conversely, a risk-averse defendant with a strong case might settle for what might seem like an overly generous amount to avoid even a small probability that a judge or jury will award an amount large enough to cripple the company. ${ }^{83}$ The authors do not believe that analysis based upon settlements would yield meaningful insights into the questions examined in this chapter.

79 15 U.S.C. $\$ 15$ (2000).

${ }^{80}$ One might believe, for example, that a settlement represents the lower bound on the expected recovery if the case would go to trial (the present value of three times the overcharge plus attorneys' fees) since a risk-neutral defendant would be unlikely to settle for the entire expected verdict.

One might also believe the supposed rule of thumb that good antitrust cases usually settle for single damages, perhaps on the dubious theory that the trebling (which produces a higher number) and the lack of prejudgment interest (which produces a lower number) would roughly usually cancel each other. The authors have no evidence as to whether this is the way that plaintiffs and defendants, or their attorneys, typically behave. The authors have, however, heard trustworthy plaintiff and defendant attorneys tell them, anecdotally, they have settled cartel cases for single damages.

${ }^{81}$ If a plaintiff and defendant each knew they had a 50\% chance of winning, the settlement might well be for 50\% of the present value of the automatically trebled overcharges. But this would not be true if a plaintiff's chance of prevailing was not $50 \%$, if one party was a better bargainer, or if the parties were unduly optimistic or pessimistic about their chances of prevailing. If a plaintiff only has a $25 \%$ chance of proving the damages, a settlement should be at far below the level of 50\% of the discounted present value of three times the overcharges.

${ }^{82}$ Plaintiffs' counsel typically assert that defense counsel habitually delay meritorious claims for years. Since antitrust awards do not contain prejudgment interest, and plaintiffs often need the money in the short term, these delays harm plaintiffs' bargaining position significantly. Plaintiffs' counsel also assert that defendants often are able to prevent class certifications and otherwise to make litigation so burdensome that plaintiffs have to settle for only a small fraction of the actual overcharges.

83 The authors have heard variations on this theme many times. Attorneys for defendants in cases that have settled for many millions of dollars appear to believe, well after the cases were over and after there was any threat of further liability, that their clients never affected prices. Defendant attorneys often assert that their clients (who were found by a court to have agreed to fix prices) were prevented by market forces from affecting prices significantly. However, rather than take the risk of having a judge or jury not believe them, they settle for a large sum.

Another factor that can make defendants want to settle even if they did not raise prices is antitrust's joint and several liability doctrine, which makes every member of a cartel liable for the overcharges of the entire cartel. This can lead to extremely large potential damages, and even a small risk of a huge payout can, from the defendant's perspective, overshadow a weak liability case. The defendant might be forced to settle for a significant amount even if it did not cause prices to be elevated. 
The authors instead attempted to obtain the largest possible sample of verdicts in collusion cases. The authors searched for final ${ }^{84}$ decisions in United States antitrust cases involving horizontal collusion, broadly defined to include bid rigging and related practices, where a judge, jury, or commission calculated damages that could be expressed in percentage terms. ${ }^{85}$

The authors were able to find only 25 final cartel verdicts, ${ }^{86}$ a small sample but one roughly as large as the surveys reported in Table 1 (which reported 5-7, 12, 12, 13, 22, and 38 cases, respectively). Nevertheless, due to the small sample set, these results should be interpreted with caution.

These 25 final verdicts had a median average overcharge of $21.6 \%$ and a mean average overcharge of $31 \% .{ }^{87}$ All but five found that the cartel raised prices by more than the U.S. Sentencing Commission's $10 \%$ benchmark.

How useful are the decisions of judges and juries in answering the question of how high cartels raise prices? While the common law system of jury and judge verdicts is far from perfect, our nation ${ }^{88}$ has made an implicit decision that judges and juries are the best way to arrive at the truth the largest percentage of the time. The authors know of no way to prove whether judges or juries achieve results better than those of the economists who publish studies in journals and books. The authors are using final decisions to supplement the more comprehensive survey reported in the previous section. Since these two major approaches reinforce one another, the credibility of each is strengthened.

\section{Conclusions and Implications}

The Antitrust Modernization Commission recently concluded: "fines under the Sherman Act are generally determined by the courts based on guidance in the Sentencing Guidelines issued by the U.S. Sentencing Commission. The Sentencing Guidelines employ a proxy of harm from cartels based on twenty percent of the volume of commerce affected. This twenty percent proxy is based on an assumed average overcharge of ten percent, which is doubled to account for dead-weight loss to society. The Commission recommends that the Sentencing Commission

\footnotetext{
${ }^{84}$ The authors excluded verdicts overturned on appeal, and cases that were not hard core, per se cartel cases.

${ }^{85}$ Many of the verdicts were only expressed in dollar amounts that we were unable to translate into percentages, so the authors reluctantly omitted these cases. See, e.g., Bigelow v. RKO Radio Pictures, 327 U.S. 251 (1946); Chattanooga Foundry \& Pipe Works v. Atlanta, 203 U.S. 390 (1906); Transnor (Bermuda) Ltd. v. BP N. Am. Petroleum, 736 F. Supp. 511 (S.D.N.Y. 1990), Phillips v. Crown Cent. Petroleum Corp., 602 F.2d 616 (4th Cir. 1979).

86 The authors surely found only a small percentage of final verdicts, and would be grateful if readers could inform them (at rlande@ ubalt.edu) of final verdicts they inadvertently omitted. For a list of these verdicts see John M. Connor \& Robert H. Lande, How High Do Cartels Raise Prices: Implications for Optimal Cartel Fines, 80 TULANE L. REV. 513, 565-70 (2005).

${ }^{87}$ The nine cases that reported peak overcharges produce a median peak overcharge of $71.4 \%$ and a mean peak overcharge of $130 \%$.

${ }^{88}$ In other nations with admirable judicial systems, judges or judicial panels are the vehicles of decisionmaking in antitrust cases, which typically are civil matters. See, e.g., the discussion of the EU approach in Marc Van der Woude and Christopher Jones, EC COMPETITION LAW HANDBOOK 593-629 (2002/2003 ed.).
} 
evaluate whether it remains reasonable to assume an overcharge of ten percent (i.e., whether it should be higher or lower)...." 89

Our survey of cartel studies has concluded that the median ${ }^{92}$ cartel overcharge for all types of cartels over all time periods has been $25 \%$; $17-19 \%$ for domestic cartels and $30-33 \%$ for international cartels. ${ }^{93}$ These figures are based upon our survey of approximately 200 serious studies of cartels which contained 674 observations of average overcharges. ${ }^{94}$ Thus, in general international cartels have been about $75 \%$ more effective in raising prices than domestic cartels. Cartel overcharges are skewed to the high side, pushing the average overcharge for all types of cartels over all time periods to $49 \%$. These results are generally consistent with the few, more limited, previously published works that survey cartel overcharges. The six surveys that seem to exhibit the highest standards of scholarship (Table 1) report samples with simple average median overcharges of $28.1 \%$ and simple average mean overcharges of $30.7 \%$ of affected sales.

In this sample, $79 \%$ of the overcharges were higher than the $10 \%$ presumption contained in the U.S. Sentencing Commission Guidelines; $60 \%$ were above $20 \%$. Perhaps surprisingly, bid rigging was no more injurious than other forms of collusion. If anything, the data suggests that bid rigging is about one-fifth less injurious. These results suggest that the U.S. Sentencing Commission should amend its Guidelines, which currently treat bid rigging more harshly than other forms of collusion. ${ }^{95}$

For most types of cartels there have been modest downtrends in cartel mark ups over time. Since 1990 the average overcharges of discovered cartels fell to $17-18 \%$ for domestic cartels, and to $25 \%$ for international cartels. ${ }^{96}$ Since the post-1990 era has been the period with by far the highest level of fines imposed, this decrease is consistent with the theory of optimal deterrence discussed in Section 1 supra. $^{97}$ It also suggests that the recent worldwide trend

\footnotetext{
${ }^{89}$ ANTITRUST MODERNIZATION COMMISSION, REPORT AND RECOMMENDATIONS, Letter to the President and The Congress of the United States, at vii (2007); available at http://www.amc.gov/report_recommendation/letter_to_president.pdf

${ }^{92}$ All figures presented in this section incorporate all relevant zero estimates and omit peak results.

${ }^{93}$ This study found results for 247 international cartel episodes and 198 domestic cartel episodes. In addition, it found significant differences in average overcharges across cartels by geographic type. Those managed in single European countries have the lowest median overcharges (17\%), but curiously those organized across national boundaries in Western Europe were as a group the most successful (43\% median overcharge). North American conspiracies also had quite low average overcharges (21\%). Median overcharges for Asian-based and global conspiracies were relatively high $(29 \%)$.

94 Average overcharges are those calculated from an entire cartel episode, not just a peak or isolated result.

95 Another minor modification is to remove the suggestion that cartels with large affected sales have smaller percentage overcharges. See John M. Connor \& Robert H. Lande, How High Do Cartels Raise Prices: Implications for Optimal Cartel Fines, 80 TUlANE L. REV. 513 (2005) at 544 (demonstrating that there is no empirical basis for the Guideline's statement that cartels are less dangerous when they are formed in larger markets.)

96 There were 137 international cartels analyzed for this period and 49 domestic cartels.

97 There has been a great deal of speculation about how price fixers behave and what incentives and deterrents they do or do not respond to. We cannot in any meaningful way truly psychoanalyze them and use these results to set up a system likely to provide them with optimal incentives. Nevertheless, the data suggests that the relevant corporate officials do respond at least somewhat to the incentives that have been created by the existing system of criminal penalties. This suggests that the current system of cartel fines has been at least partly successful, continuing and intensifying a trend that began in the early $20^{\text {th }}$ century.
} 
towards the intensification of cartel penalties has been desirable. If criminal fines correspond more closely to the actual levels of cartel overcharges, sanctions against price fixing will more closely provide optimal deterrence.

Our survey of final verdicts in U.S. collusion cases, only three of which were international cartels, showed an average median overcharge of $21.6 \%$ and an average mean overcharge of $31 \% .^{98}$ These figures are quite comparable to the results of the much larger set of economic estimates. $^{99}$

All told, the data thus shows that median cartel overcharges are in fact two or three times as high as the level presumed by the U.S. Sentencing Commission, and the average cartel overcharges are three to five times as high. The Commission's base fine levels, built around a presumption of a $10 \%$ overcharge, even when adjusted by significant culpability multipliers, ${ }^{100}$ are likely to be far too low to deter most cartels. ${ }^{101}$

There are, moreover, important respects in which this chapter's methodology has been conservative. It has focused solely upon the injury that arises from the transfer of income or wealth from purchasers to the cartel. As noted in Section 1, cartels also can lead to allocative inefficiency, umbrella effects, less innovation, managerial slack, and to nonprice harms to quality and variety, etc. Yet, this paper has not taken these additional harms into account. Nor has it adjusted the results for inflation. ${ }^{102}$ Admittedly, most of these factors can be difficult to measure. Nevertheless, while the Guidelines seem to have doubled the $10 \%$ presumption to account for their omission of these factors, the authors believe that this doubling has been overly conservative. Yet, none of these factors account for the fact that the enforcers probably uncover only a modest percentage of illegal cartels. This factor alone suggests that the current Guideline fine levels are likely to be far too low.

\footnotetext{
${ }^{98}$ In addition, these nine cases that reported peak overcharges produce a median peak overcharge of $71.4 \%$ and a mean peak overcharge of $130 \%$.

${ }_{99}$ All but five of the reported decisions found that the cartel had raised prices by more than the U.S. Sentencing Commission's 10\% benchmark. Because of the relatively small number of verdicts, however, it is improper to place much weight on sub-groups of these data. For example, only eight reported verdicts involved bid rigging, so it does not seem worthwhile for this article to report the median or mean figures for bid rigging verdicts.
}

${ }^{100}$ For a variety of factors, however, one former prosecutor claims that few firms actually pay a fine amounting to $20 \%$ of the amount of commerce affected. Most violators have their fines reduced for a variety of reasons. Gary R. Spratling, Detection and Deterrence: Rewarding Informants for Reporting Violations 69 GEO. WASH. L. REV. 798 (2001).

101 The Guideline's 10\% overcharge presumption was, moreover, based upon the estimate that "the average gain from price-fixing is $10 \%$ of the selling price." UNITED STATES SENTENCING GUIDELINES MANUAL §2R1.1, application n.3. (2005) The Guideline's average is the equivalent of the mean, not the median. The correct comparisons are therefore not between the Guideline's figure of $10 \%$ and the medians of $25 \%$ for the economic studies and $22 \%$ for the case verdicts. Rather, the truer comparison would be to the mean figures of $49 \%$ and $31 \%$, respectively. It is unclear on the question of whether, from the perspective of optimal deterrence, mean or median figures should be used as the basis of the U.S. Sentencing Commission's presumption. The decision to focus on the median figures has been a conservative one.

102 Suppose a cartel overcharges in years 1 through 7, followed by discovery and another 3 years of litigation. The penalties would be assessed in year 10. The overcharges from year 1 really should be adjusted for 9-10 years of inflation, but this paper has not done this. This omission means that the paper's penalty recommendations are too low. 
For these reasons, if the U.S. Sentencing Commission decides to reexamine whether $10 \%$ is the right overcharge presumption, ${ }^{103}$ it should consider raising the presumption to at least $15 \%$ for domestic cartels, and to at least $25 \%$ for international cartels. Alternatively, if the policymakers decide that this distinction is unwise, a minimum of a $20 \%$ overall presumption would be appropriate. This is a conservative and modest proposal in light of this article's demonstration that cartels typically generate a median of at least two or three times the harms presumed by the current Sentencing Guidelines, and a mean of at least three to five times these amounts.

Before the recent decision in United States v. Booker, ${ }^{104}$ a jury determined whether a violation occurred, and the sentencing judge determined the volume of commerce affected by the violation by a preponderance of the evidence standard. Then, using the Sentencing Guidelines, the judge relied on the U.S. Sentencing Commission's presumption that the defendant raised prices by $10 \%$ of the volume of affected commerce, doubled this figure, ${ }^{105}$ and used tabulated culpability factors to adjust this amount. ${ }^{106}$ If the fine would have exceeded the statutory maximum of $\$ 100$ million, ${ }^{107}$ the enforcers had to rely on the alternative sentencing provision of twice-the-gain or twice-the-loss. ${ }^{108}$

After Booker the government will have to prove to a jury the amount of commerce involved beyond a reasonable doubt. This should not, however, prove to be a significant additional burden, ${ }^{109}$ so most cases involving potential fines of less than $\$ 100$ million should not be significantly ${ }^{110}$ affected by Booker except insofar as the Guidelines' criteria will be advisory instead of mandatory (and even this might not make much difference in practice ${ }^{111}$ ).

103 United States $v$ Booker, 543 U.S. 220 (2005) means that the $10 \%$ presumption will not be employed in cases where the fine should exceed $\$ 100$ million.

104543 U.S. 220 (2005).

105 See U.S. SENTENCING GUIDELINES MANUAL § 2R1.1, comment 3 (2006)..

106 Some of the adjustment factors, such as whether defendant was the organizer or leader or a cartel, increase the fine level, and some lower it. See United States Sentencing Guidelines Manual §2R1.1, application note 1. (2005). The maximum range is from $15 \%$ to $80 \%$ of affected commerce.

107 In 2004 the maximum was increased from a $\$ 10$ million to a $\$ 100$ for corporations, and from $\$ 350,000$ to $\$ 1$ million for individuals. See Antitrust Criminal Penalty Enhancement and Reform Act of 2004, Pub. L. No. 108-237, 118 Stat. 661 (2004).

108 See 18 U.S.C. $\$ 3571(\mathrm{~d})$ (2000). In practice, however, every case whose fine exceeded the statutory maximum settled. By choosing to settle, defendants made a calculated decision not to take the risk that the government would be able to prove an extremely large fine under the twice-the-gain or twice-the-loss standard, and instead settled for a significantly lower amount. See Tara L. Reinhart, Nathan J. Muyskens \& Christopher E. Tierney, Facing the Facts After Blakely, Booker, and Fanfan, THE ANTITRUST SOURCE, (Jan. 2005), available at http://antitrustsource.com

109 Nor should it be unduly difficult for the government to prove whether the defendant was a leader or organizer or the cartel, or, the other factors that would lead to increases in the fine.

110 For additional effects see Tara L. Reinhart, Nathan J. Muyskens \& Christopher E. Tierney, Facing the Facts After Blakely, Booker, and Fanfan, THE ANTITRUST SOURCE, (Jan. 2005), available at http://antitrustsource.com .

111 See Gary Fields \& Laurie P. Cohen, Judges Maintain Sentence Formula Despite Ruling, WALL ST. J., Feb. 11, 2005, at A5. The Chair of the Sentencing Commission testified before a House Subcommittee that preliminary data, involving 692 cases, shows that virtually the same percentage of sentences in post-Booker cases as in pre-Booker cases were within the Sentencing Guidelines' ranges. 
For the largest cartels ${ }^{112}$, however, Booker could have a significant impact because the twice-the-gain or twice-the-loss fine now will have to be proven to a jury beyond a reasonable doubt. Due the challenges of estimating antitrust damages, this may prove a truly formidable task. ${ }^{113}$ However, the Department of Justice could attempt to circumvent the possibly $\$ 100$ million de facto cap on fines ${ }^{114}$ by returning to its former practice of splitting antitrust charges into multiple counts, by product or geographic market, for what could be argued to be the same cartel; ${ }^{115}$ and by adding multiple counts of mail fraud, ${ }^{116}$ wire fraud, ${ }^{117}$ or RICO violations for what essentially are antitrust offenses. ${ }^{118}$ By doing this the Department could attempt to effectively increase the antitrust fines involving the largest cartels in a manner more likely to lead to the optimal deterrence of antitrust offenses.

112 That is, all cartelists with affected sales of $\$ 666$ million or more and minimal culpability. However for members of the cartel with typical culpability scores, cartel participants with as little as \$125 million in affected commerce and maximum culpability scores are affected by the statutory cap.

113 Knowing the great difficulty the government would face if the case went to court, defendants should demand lower fines when they are plea bargaining, and some defendants might be less likely to reach plea agreements and more likely to take their chances in court. A jury would decide the twice-the-gain or twice-the-loss issue largely on the basis of testimony from economic experts, who would have to convincingly analyze huge amounts of complicated data about market events and price trends and levels. It could be extremely difficult for a government expert to convince a jury that prices rose a particular amount beyond a reasonable doubt, particularly since the defendant would have an equally qualified expert testifying in its favor.

114 Moreover, in response to Booker, Congress might well pass legislation to preserve as much of the Sentencing Guidelines as is permissible constitutionally or to increase the maximum fine under the Sherman Act.

115 For example, in United States $v$. Allied Chemical \& Dye Corp., which involved an international fertilizer nitrogen cartel, the DOJ successfully charged the same defendants with eleven separate Sherman Act violations. 42 F. Supp. 425, 426 (S.D.N.Y. 1941). Many of the largest cartels have involved multiple products. See, e.g., John M. Connor, GLOBAL PRICE FIXING (2 ${ }^{\mathrm{ND}}$ ed.) at 237-339 (2007) (analyzing the many products at issue in the international vitamin cartel case).

116 See United States v. Brighton Building \& Maintenance Co., 598 F. 2d 1101 ( ${ }^{\text {th }}$ Cir. 1978).

117 See United States v. Ames Sintering Co., 927 F. 2d 232 (6 $6^{\text {th }}$ Cir. 1990).

${ }^{118}$ See Municipality of Anchorage v. Hitachi Cable, Ltd., 547 F. Supp. 633 (D. Alaska 1982). 